\title{
PERAN PSYCHOLOGICAL DETAHCMENT DALAM MENGATUR HUBUNGAN ANTARA JOB STRESS DAN WELL-BEING PADA PERAWAT
}

\author{
Juwita ${ }^{1}$, Andy Saputra ${ }^{2}$ Elisa $^{3}$, Maria Theresia ${ }^{4}$ dan Tommy Y. S. Suyasa ${ }^{5}$ \\ ${ }^{1}$ Fakultas Psikologi, Universitas Tarumanagara \\ Email: Juwita.tan99@gmail.com \\ ${ }^{2}$ Fakultas Psikologi, Universitas Tarumanagara \\ Email: andy.saputra1994@gmail.com \\ ${ }^{3}$ Fakultas Psikologi, Universitas Tarumanagara \\ Email: elisacj92@gmail.com \\ ${ }^{4}$ Fakultas Psikologi, Universitas Tarumanagara \\ Email: tessa1311@gmail.com \\ ${ }^{5}$ Staf Pengajar Fakultas Psikologi, Universitas Tarumanagara \\ Email: sumatera.suyasa@gmail.com
}

\begin{abstract}
Nurses who frequently think of work outside working hours may cause low well-being for themselves. This can, in turn, create high level of job stress. This study aims to determine the role of psychological detachment in regulating the relation between job stress and well-being in nurses. The subjects of this study are nurses who work in various health institutions located in Tangerang. This study involves 103 subjects, consisting of 88 women and 15 men with an age range of 19-57 years. The method used in this study is quantitative, with the type being correlational research. The results showed that psychological detachment had a role in regulating the relation between job stress and well-being on nurses. However, the role of job stress on negative well-being indicator is more significant than the role of psychological detachment on negative indicator of well-being.
\end{abstract}

Keywords: psychological detachment, job stress, well-being.

\begin{abstract}
ABSTRAK
Perawat yang sering memikirkan pekerjaan di luar jam kerja dapat menimbulkan rendahnya well-being. Hal tersebut dapat memicu tingkat job stress yang tinggi. Penelitian ini bertujuan untuk mengetahui peran psychological detachment dalam mengatur hubungan antara job stress dan well-being pada perawat. Subyek penelitian ini adalah perawat yang bekerja pada berbagai instansi kesehatan yang berlokasi di Tangerang. Penelitian ini melibatkan 103 subyek, yang terdiri dari 88 orang perempuan dan 15 orang laki-laki dengan rentang usia 19-57 tahun. Metode yang digunakan dalam penelitian ini adalah metode kuantitatif dengan jenis penelitian korelasional. Hasil penelitian menunjukkan bahwa psychological detachment berperan dalam mengatur hubungan antara job stress dan well-being pada perawat. Namun, peran job stress terhadap indikator negatif well-being lebih signifikan daripada peran psychological detachment terhadap indikator negatif well-being.
\end{abstract}

Kata Kunci: psychological detachment, job stress, well-being.

\section{PENDAHULUAN}

\section{Latar Belakang}

Profesi perawat merupakan profesi yang memberikan pelayanan dengan tujuan meningkatkan kesehatan dan kesejahteraan individu, khususnya yang merupakan pasien dalam rumah sakit (Potter \& Perry, 2005). Perawat sangat berperan dalam proses medis; dalam rumah sakit, perawat adalah salah satu tenaga kerja yang sangat penting. Setiap hari, para perawat bekerja selama 24 jam untuk menjaga dan merawat pasien. Seorang perawat yang profesional berperan sebagai pemberi asuhan keperawatan, pendidik, advokat, konsultan, komunikator, dan manajer. 
Selanjutnya, profesi perawat merupakan profesi yang sangat menuntut secara fisik dan emosional, dan perawat seringkali melaporkan berbagai keluhan fisik dan emosional (Cheung \& Yip, 2015; Perry, Lamont, Brunero, Gallagher, \& Duffield, 2015; Letvak, 2014). Di Inggris, Kirk (2015) melaporkan bahwa para perawat dapat merasa sangat terbeban oleh pekerjaan mereka sehingga jatuh sakit dan harus mengambil cuti selama rata-rata 51 hari per tahun. Dalam psikologi, keluhan fisik yang disebabkan oleh faktor psikologis disebut sebagai psychosomatic complaints, dan psychosomatic complaints telah ditemukan sering dialami oleh perawat (Humaida, 2012; Fronteira \& Ferrinho, 2011). Beberapa psychosomatic complaints yang telah dilaporkan oleh para perawat termasuk rasa sakit di berbagai bagian tubuh (seperti kepala, punggung, perut, atau berbagai area otot), kesulitan tidur, muntah-muntah, tingkat asam lambung yang tinggi, sering merasa letih, hipertensi, dan irritable bowel syndrome (Yu, 2016; Perry et al., 2015; Humaida, 2012; Fronteira \& Ferrinho, 2011). Para perawat bahkan telah ditemukan sering mengalami musculoskeletal disorders, memiliki kemungkinan lebih tinggi untuk mengalami tuberkulosis dan infeksi patogen, dan juga lebih banyak memiliki occupational allergies daripada masyarakat umum.

Selain keluhan fisik, para perawat juga sering melaporkan berbagai keluhan emosional (Cheung \& Yip, 2015; Perry, Lamont, Brunero, Gallagher, \& Duffield, 2015; Letvak, 2014; Humaida, 2012). Keluhan-keluhan emosional tersebut termasuk merasa frustasi dengan pekerjaan, merasa memiliki beban pekerjaan yang besar, dan merasa letih. Dalam psikologi, keluhan-keluhan tersebut merupakan tanda-tanda dari emotional exhaustion, di mana emotional exhaustion didefinisikan sebagai perasaan telah bekerja terlalu banyak dan merasa sangat letih (Vahey, Aiken, Sloane, Clarke, \& Vargas, 2004).

Dalam psikologi, fenomena psychosomatic complaints dan emotional exhaustion yang dialami oleh para perawat dapat diistilahkan sebagai rendahnya well-being. Definisi well-being menurut Ryan \& Deci (2001) adalah kesejahteraan atau fungsi individu yang positif. Well-being dapat dijelaskan melalui indikator-indikator negatif, termasuk psychosomatic complaints dan emotional exhaustion (Petinadou, 2013; Perry et al., 2015).

Berbagai penelitian telah menemukan bahwa stres yang dialami karena pekerjaan, atau job stress, dapat menyebabkan tingkat well-being yang rendah ( $\mathrm{Yu}, 2016$; Cheung \& Yip, 2015; Kirk, 2015; Letvak, 2014; Roberts, Grubb, \& Grosch, 2012). Sejalan dengan penemuan tersebut, terdapat berbagai laporan bahwa para perawat sering mengalami job stress; hal ini ditemukan baik di luar dan di dalam Indonesia (Jundillah, 2017; Eryuda, 2017; Yu, 2016; Kristianti, 2016; Wibowo, 2016; Hendarwati, 2015; Cheung \& Yip, 2015; Kirk, 2015; Yana, 2014; Suryani \& Waluyanti, 2013; Jusnimar, 2012; Ratnaningrum, 2012; Martina, 2012).

Penelitian Sonnentag dan Bayer (2005) juga menemukan bahwa kondisi rendahnya well-being dapat diprediksi oleh beban kerja yang berlebih; dalam kata lain, saat beban kerja (job stress) tinggi, maka well-being akan rendah. Namun selain itu, Sonnentag dan Bayer juga menemukan hal lain yang menarik; jika individu memiliki kemampuan psychological detachment, maka individu dapat memiliki well-being yang tinggi walaupun beban kerja yang dialami juga tinggi. Psychological detachment merupakan keadaan di mana individu mampu memisahkan diri secara mental dari pekerjaannya (Sonnentag, 2012). Dalam kata lain, individu melakukan psychological detachment saat ia sedang berada di luar waktu atau ruang kerja dan tidak memikirkan isu-isu mengenai pekerjaannya.

Hasil penelitian Sonnentag dan Bayer (2005) belum tentu dapat digeneralisasikan atau ditetapkan pada profesi perawat, karena adanya perbedaan karakteristik antara partisipan penelitian Sonnentag dan Bayer dan profesi perawat. Partisipan pada penelitian Sonnentag dan Bayer memiliki karakteristik sebagai berikut: memiliki latar belakang profesional yang luas (termasuk supervisor atau staf dalam berbagai perusahaan, dan individu self-employed), memproduksi dan memberikan beragam macam produk atau jasa yang luas (termasuk software 
komputer, produk farmakologi, jasa konsultasi, jasa distribusi, dan jasa publik), dan memiliki pekerjaan yang menuntut (demanding). Sedangkan, para perawat memiliki latar belakang profesional yang relatif sempit, dan memberikan jasa yang relatif sempit (yaitu jasa medis, dan lebih spesifiknya lagi jasa medis yang hanya dilakukan oleh perawat). Walaupun partisipan penelitian Sonnentag dan Bayer dideskripsikan memiliki pekerjaan yang menuntut, terdapat kemungkinan bahwa perawat memiliki pekerjaan yang lebih menuntut dan membebankan daripada para partisipan tersebut. Dalam profesi perawat, kesalahan tidak dapat ditoleransi; setiap kekeliruan (seperti kesalahan dalam pengobatan, pasien yang jatuh, atau pasien yang terlantar) dapat membahayakan keselamatan pasien dan menyebabkan biaya lebih, tuntutan hukum, dan protes dari publik (Cheung \& Yip, 2015). Setiap perawat memiliki tanggung jawab hukum, etika, moral, dan profesional secara individual untuk kesalahan pengobatan atau insiden dengan pasien yang diduga disebabkan oleh sang perawat. Maka, dugaan bahwa perawat merupakan profesi yang lebih menuntut daripada profesi para partisipan penelitian Sonnentag dan Bayer bukanlah asumsi yang tidak wajar. Dengan ini, berbagai perbedaan karakteristik antara profesi perawat dan profesi para partisipan penelitian Sonnentag dan Bayer dapat saja akan menyebabkan perbedaan hasil penelitian.

Pada penelitian ini, tim peneliti akan beranjak dari penemuan penelitian Sonnentag dan Bayer (2005) mengenai hubungan antara psychological detachment, job stress, dan well-being. Namun, penelitian ini akan berbeda dari penelitian Sonnetag dan Bayer, dalam hal karakteristik partisipan. Partisipan penelitian ini adalah perawat, yang secara teori memiliki tuntutan pekerjaan lebih berat, dan kemungkinan memiliki job stress yang lebih tinggi. Berdasarkan penjelasan di atas maka tujuan dari penelitian ini adalah untuk mengetahui bagaimana peran psychological detachment dalam mengatur hubungan antara job stress dan well-being pada perawat.

\section{METODE PENELITIAN \\ Partisipan Penelitian}

Sampel dalam penelitian yang dipakai dalam penelitian ini adalah perawat yang bekerja pada berbagai instansi kesehatan di daerah Tangerang. Penelitian ini tidak dibatasi oleh umur, jenis kelamin, agama, suku atau ras tertentu dan tidak membatasi status sosial ekonomi. Jumlah sampel pada penelitian ini adalah 103 orang, yang terdiri dari 88 orang perempuan dan 15 orang laki-laki dengan rentang usia 19-57 tahun. Penelitian ini menggunakan teknik pengambilan sampel nonprobability sampling, dengan jenis penarikan sampel yaitu teknik purposive sampling.

\section{Alat Ukur}

Kuesioner indikator negatif well-being terbagi atas dua bagian yaitu emotional exhaustion dan psychosomatic complaints. Kuesioner emotional exhaustion terdiri atas tujuh butir item positif dan tujuh butir item negatif, serta kuesioner psychosomatic complaints yang terdiri atas 32 butir item positif dan tiga butir item negatif. Kuesioner job stress terdiri dari 68 butir item positif, sedangkan kuesioner psychological detachment terdiri dari 34 butir item.

Alat ukur indikator negatif well-being terbagi atas dua bagian yaitu emotional exhaustion dan psychosomatic complaints. Alat ukur emotional exhaustion diperoleh dari Wilk dan Moynihan (2005) serta Senecal, Vallerand, dan Guay (2001) yang telah diadaptasi ke Bahasa Indonesia. Sedangkan alat ukur psychosomatic complaints diperoleh dari Greller dan Parsons (1988) yang juga telah diadaptasi ke Bahasa Indonesia.

Alat ukur job stress diperoleh dari Badan Riset dan Pengukuran Universitas Tarumangara. Sedangkan alat ukur psychological detachment diperoleh dari Badan Riset dan Pengukuran Universitas Tarumanagara.

\section{HASIL DAN PEMBAHASAN}




\section{Hasil Penelitian}

Tabel 1 Statistik Deskriptif Indikator Well-Being pada Partisipan

\begin{tabular}{llllll}
\hline Well-being & Minimum & Maksimum & Rata-rata & Simpangan baku \\
\hline Psychosomatic complaints & $+1,15$ & 3,87 & 2,3280 & 0,55973
\end{tabular}

Emotional exhaustion

Setelah pengambilan data, peneliti mengolah data dan menemukan rata-rata skor indikator negatif well-being (psychosomatic complaints dan emotional exhaustion) sebesar 2,33 dan simpangan baku sebesar 0,56 pada seluruh sampel $(n=103)$. Pada rentang skor 1 sampai 5 (rendah $=<3$; rata-rata $=3$; tinggi $=>3$ ), skor rata-rata indikator negatif well-being partisipan penelitian ini tergolong pada kategori rendah. Hal ini menunjukkan bahwa partisipan penelitian ini cenderung mengalami kelelahan emosi (frustrasi, letih, terbebani, tidak semangat, dan jenuh) dan keluhan fisik (sulit tidur, sakit perut, tangan bergemetar, mual, dan sesak nafas) yang jarang.

Tabel 2 Statistik Deskriptif Dimensi Indikator Negatif Well-Being pada Partisipa

\begin{tabular}{lccccc} 
Well-being & $\mathrm{N}$ & Minimum & Maksimum & Rata-rata & Simpangan baku \\
& 103 & 1,00 & 3,50 & 2,1996 & 0,56927 \\
\hline $\begin{array}{l}\text { Psychosomatic } \\
\text { complaints }\end{array}$ & 103 & 1,00 & 4,80 & 2,4563 & 0,76564
\end{tabular}

Rata-rata skor psychosomatic complaints partisipan adalah sebesar 2,20 dengan simpangan baku sebesar 0,57. Hal ini menunjukkan bahwa pada rentang skor 1 sampai 5 (rendah $=<3$; rata-rata $=3$; tinggi $=>3$ ), secara umum partisipan memiliki tingkat psychosomatic complaints yang tergolong rendah. Rata-rata skor emotional exhaustion partisipan adalah sebesar 2,46 dengan simpangan baku sebesar ,77. Hal ini menunjukkan bahwa pada rentang skor 1 sampai 5 (rendah $=<3$; rata-rata $=3$; tinggi $=>3$ ), secara umum partisipan memiliki tingkat emotional exhaustion yang tergolong pada kategori rendah. Hasil rerata tersebut menunjukkan bahwa secara umum, partisipan memiliki tingkat kelelahan emosi (frustrasi, letih, terbebani, tidak semangat dan jenuh) yang lebih tinggi dibandingkan dengan tingkat keluhan fisik (sulit tidur, sakit perut, tangan bergemetar, berjerawat, mual dan sesak nafas).

Tabel 3 Statistik Deskriptif Job Stress pada Partisipan

\begin{tabular}{llllll}
\hline Job stress & $\mathrm{N}$ & Minimum & Maksimum & Rata-rata & Simpangan baku \\
& & & & \\
\hline Job stress index & 103 & 1,50 & 9,15 & 5,1223 & 1,57723 \\
\hline
\end{tabular}

Rata-rata skor job stress partisipan adalah sebesar 5,12 dengan simpangan baku sebesar 1,58. Berdasarkan rentang skor 1 sampai 8 (rendah $=<4,5$; rata-rata $=4,5$; tinggi $=>4,5$ ), tingkat job stress yang dialami partisipan secara umum tergolong pada kategori tinggi. Hal ini 
menunjukkan bahwa partisipan cenderung sering merasa adanya tolakan terhadap hasil kerja, terganggu oleh atasan, sulit mengerti tugas, ada hambatan komunikasi dan mengalami sikap kasar dengan rekan kerja, dan partisipan juga cenderung merasa terbebani oleh hal-hal tersebut.

Tabel 4 Statistik Deskriptif Psychological Detachment pada Partisipan

\begin{tabular}{llllll}
\hline $\begin{array}{l}\text { Psychological } \\
\text { detachment }\end{array}$ & N & Minimum & Maksimum & Rata-rata & Simpangan baku \\
\hline 103 & 1,00 & 5,86 & 3,3491 & 0,68103 \\
\hline
\end{tabular}

Rata-rata skor psychological detachment partisipan adalah sebesar 3,35 dengan simpangan baku sebesar 0,68. Berdasarkan rentang skor 1 sampai 6 (rendah $=<3,5$; rata-rata $=$ 3,5; tinggi $=>3,5)$, maka dapat dikatakan bahwa secara umum partisipan memiliki tingkat psychological detachment yang tergolong rendah. Hal tersebut mengimplikasikan bahwa partisipan cenderung tidak melupakan hal-hal yang berkaitan dengan pekerjaan, merasa tidak bebas, dan terbebani oleh pekerjaannya walau di luar jam kerja.

Hasil analisa general linear model univariate terhadap variabel-variabel psychological detachment, job stress, dan indikator negatif well-being menunjukkan bahwa psychological detachment memiliki peran yang kecil dalam hubungan antara job stress dan indikator negatif well-being (efek interaksi $=2,78 \%$ ). Selain itu, job stress ditemukan memiliki hubungan yang signifikan dengan indikator negatif well-being $(r=0,365, p=0,000 ;<0,001)$. Berdasarkan hasilhasil tersebut, dapat dikatakan bahwa peran job stress terhadap indikator negatif well-being lebih signifikan daripada peran psychological detachment terhadap indikator negatif well-being. Maka, saat dibandingkan dengan kemampuan individu untuk melupakan pekerjaan di luar jam kerja, beban individu terhadap adanya tolakan terhadap hasil kerja, terganggu oleh atasan, sulit mengerti tugas, ada hambatan komunikasi dan mengalami sikap kasar dengan rekan kerja cenderung lebih berperan pada tingkat kelelahan emosi (seperti frustrasi, letih, terbebani, tidak semangat dan jenuh) dan keluhan fisik (seperti kesulitan tidur, sakit perut, tangan bergemetar, berjerawat, mual dan sesak nafas). Walaupun dalam efek yang kecil, melupakan pekerjaan di luar jam kerja dapat meningkatkan kesejahteraan individu ketika beban kerja individu tinggi.

Tabel 5 Tingkat Rata-rata Indikator Negatif Well-being

Job stress

Rendah Tinggi Total

$\begin{array}{ccccc}\begin{array}{c}\text { Psychological } \\ \text { detachment }\end{array} & \text { Rendah } & -.4851 & .7140 & -.0854\end{array}$




$\begin{array}{llll}\text { Rata-rata } & -.1493 & .3981 & -.0184 \\ \text { Tinggi } & -.3029 & -.3252 & -.3051 \\ & & & \\ \text { Total } & -.2767 & .4273 & -.1195\end{array}$

Tabel 6 Jumlah Sampel berdasarkan Kategori

\begin{tabular}{lll} 
& Value Label & $\mathrm{N}$ \\
\hline Kategori Psychological detachment & Rendah & 27 \\
\cline { 2 - 3 } & Rata-rata & 46 \\
\cline { 2 - 3 } & Tinggi & 30 \\
\hline Kategori job stress & Rendah & 80 \\
\cline { 2 - 2 } & Tinggi & 23
\end{tabular}

Tabel 7 General Linear Model Univariate, Psychological Detachment, Job Stress dan Well-being

\begin{tabular}{|c|c|c|c|c|c|}
\hline Source & $\begin{array}{l}\text { Type III Sum } \\
\text { of Squares }\end{array}$ & $\mathrm{df}$ & Mean Square & $\mathrm{F}$ & Sig. \\
\hline Corrected Model & $12.670^{\mathrm{a}}$ & 5 & 2.534 & 2.497 & .036 \\
\hline Intercept & .034 & 1 & .034 & .034 & .854 \\
\hline PsyD_Cat & 1.716 & 2 & .858 & .846 & .432 \\
\hline JSI_SQRT_Cat1 & 4.527 & 1 & 4.527 & 4.462 & .037 \\
\hline $\begin{array}{l}\text { PsyD_Cat } \\
\text { JSI_SQRT_Cat1 }\end{array}$ & 3.095 & 2 & 1.547 & 1.525 & .223 \\
\hline
\end{tabular}




\begin{tabular}{|l|r|r|r|} 
Error & 98.426 & 97 & 1.015 \\
Total & 112.567 & 103 & \\
Corrected Total & 111.096 & 102 & \\
\hline
\end{tabular}

Hasil analisa general linear model univariate terhadap variabel-variabel psychological detachment, job stress, dan indikator negatif well-being menunjukkan bahwa psychological detachment memiliki peran yang kecil dalam hubungan antara job stress dan indikator negatif well-being (efek interaksi $=2,78 \%$ ). Selain itu, job stress ditemukan memiliki hubungan yang signifikan dengan indikator negatif well-being $(r=0,365, p=0,000 ;<0,001)$. Berdasarkan hasil- 
hasil tersebut, dapat dikatakan bahwa peran job stress terhadap indikator negatif well-being lebih signifikan daripada peran psychological detachment terhadap indikator negatif well-being. Maka, saat dibandingkan dengan kemampuan individu untuk melupakan pekerjaan di luar jam kerja, beban individu terhadap adanya tolakan terhadap hasil kerja, terganggu oleh atasan, sulit mengerti tugas, ada hambatan komunikasi dan mengalami sikap kasar dengan rekan kerja cenderung lebih berperan pada tingkat kelelahan emosi (seperti frustrasi, letih, terbebani, tidak semangat dan jenuh) dan keluhan fisik (seperti kesulitan tidur, sakit perut, tangan bergemetar, berjerawat, mual dan sesak nafas). Walaupun dalam efek yang kecil, melupakan pekerjaan di luar jam kerja dapat meningkatkan kesejahteraan individu ketika beban kerja individu tinggi.

Tabel 8 Korelasi Spearman Job Stress dan Indikator Negatif Well-being

\begin{tabular}{cccc} 
& $\mathrm{N}$ & Correlation Coefficient & $p$ \\
\hline $\begin{array}{c}\text { Job stress } \\
\text { negatif } \text { well-being }\end{array}$ & 103 & 0,365 & 0,000 \\
\hline
\end{tabular}

\section{Pembahasan}

Menurut hasil penelitian ini, para perawat memiliki tingkat well-being yang termasuk di kategori tinggi, berbeda dari tinjauan fenomena yang menemukan bahwa perawat sering memiliki well-being yang rendah. Salah satu hal yang dapat menjelaskan perbedaan ini adalah waktu kerja per hari. Rata-rata jam kerja per hari para partisipan penelitian ini adalah delapan jam; sedangkan, jam kerja perawat pada tinjauan fenomena dilaporkan lebih lama. Di Amerika Serikat dan Inggris, para perawat dapat bekerja hingga 12 jam per hari (Yu, 2016; Parry, 2015). Maka, dalam kehidupan sehari-hari, para partisipan penelitian menghabiskan lebih sedikit waktu pada pekerjaan mereka yang menuntut dan menyebabkan job stress; sedangkan, para perawat dari tinjauan fenomena bekerja dan mengalami job stress per hari dalam waktu yang lebih lama. Hal ini dapat menyebabkan para perawat dalam penelitian ini melaporkan psychosomatic complaints dan emotional exhaustion yang lebih rendah, dan karenanya well-being yang lebih tinggi, dibandingkan dengan perawat dari tinjauan fenomena, walaupun para partisipan penelitian tetap mengalami job stress yang tinggi selama waktu kerja.

Hasil penelitian ini juga menemukan bahwa psychological detachment berperan dalam hubungan job stress dan indikator negatif well-being, sesuai dengan studi acuan penelitian ini oleh Sonnentag dan Bayer (2005). Namun, pada penelitian ini job stress ditemukan memiliki peranan yang lebih besar terhadap indikator negatif well-being dibandingkan dengan psychological detachment. Saat job stress yang dialami para partisipan tinggi, hanya para partisipan dengan psychological detachment tinggi yang dapat mengalami well-being tinggi, sedangkan para partisipan yang mengalami job stress tinggi tetapi memiliki psychological detachment tingkat sedang atau rendah akan memiliki well-being yang rendah. Salah satu penjelasan untuk hal ini adalah para perawat memiliki beban kerja yang cukup besar, di mana mereka harus bertanggung jawab terhadap kesehatan para pasien; setiap kesalahan yang dilakukan dapat berdampak besar pada kesehatan seseorang (Potter \& Perry, 2005). Sehari-hari, para perawat harus selalu sadar dan mengantisipasi segala kebutuhan dokter dalam menangani pasien, dan harus memikirkan dan mempersiapkan segala hal yang akan diperlukan kedepannya, walaupun di luar jam kerja; dengan kata lain, beban kerja perawat sulit untuk diabaikan di luar jam kerja karena perawat dibiasakan untuk bersiap-siaga akan segala situasi medis yang akan terjadi (Yanti, komunikasi personal, Mei 26, 2017). Dengan demikian, akan sulit bagi perawat untuk melakukan psychological detachment, dan menjelaskan mengapa para partisipan memiliki 
psychological detachment rendah. Maka dari itu, peran job stress pada well-being akan lebih besar daripada peran psychological detachment.

\section{KESIMPULAN DAN SARAN Kesimpulan}

Berdasarkan hasil penelitian, para perawat ditemukan memiliki rata-rata tingkat wellbeing yang cenderung tinggi; hal ini berbeda dengan hasil tinjauan pustaka, dan dapat dijelaskan dengan jumlah jam kerja, di mana para partisipan penelitian ini menghabiskan lebih sedikit waktu pada pekerjaan mereka dibandingkan para perawat di tinjauan pustaka. Rata-rata tingkat job stress para partisipan penelitian ditemukan termasuk dalam kategori tinggi; hal ini sejalan dengan tinjauan fenomena yang menyatakan bahwa perawat seringkali mengalami job stress yang tinggi. Penelitian ini juga menemukan bahwa job stress berhubungan secara positif dengan indikator negatif well-being, sesuai dengan tinjauan pustaka. Selain itu, hasil penelitian ini juga menemukan bahwa perawat memiliki rata-rata tingkat psychological detachment yang termasuk dalam kategori rendah; hal ini menunjukkan bahwa para perawat secara umum cenderung tidak melupakan pekerjaannya walaupun di luar jam kerja. Berdasarkan wawancara pribadi dengan seorang perawat, dijelaskan bahwa hal ini terjadi karena perawat memiliki tanggung jawab yang besar dan tidak dapat diabaikan walaupun di luar jam kerja. Hal tersebut juga membuat job stress memiliki peranan yang lebih besar terhadap indikator negatif well-being perawat, daripada peran yang dimiliki psychological detachment pada indikator negatif well-being; para perawat jarang dapat melakukan psychological detachment, sehingga kesejahteraan para perawat lebih bergantung pada job stress.

\section{Saran}

Pada penelitian ini, peneliti menggunakan indikator negatif well-being untuk mengukur well-being partisipan; dari pengalaman pribadi tim peneliti, hal ini kadang dapat mempersulit interpretasi dan diskusi mengenai hasil penelitian, di mana konsep indikator negatif well-being dan well-being membingungkan bagi peneliti, karena definisi dan konsepnya sering tertukar satu sama yang lain. Maka, peneliti dalam penelitian berikutnya disarankan untuk menggunakan alat ukur well-being dengan indikator positif.

Selain itu, untuk mengurangi job stress, para perawat disarankan agar mampu untuk tidak memikirkan hal-hal yang berkaitan dengan pekerjaannya saat di luar jam kerja; dengan kata lain, para partisipan disarankan agar lebih mampu untuk melakukan psychological detachment. Hal ini dapat membantu meningkatkan well-being para perawat agar menjadi lebih baik. Selain itu, para partisipan juga disarankan untuk meningkatkan keyakinan pribadi bahwa mereka dapat menangani beban kerjanya dengan baik, sehingga mereka dapat mempersepsikan pekerjaan mereka sebagai pekerjaan yang walaupun berat tetapi tetap mampu mereka tangani; hal ini diharapkan dapat menurunkan tingkat job stress yang mereka alami.

\section{Ucapan Terima Kasih}

Terima kasih kami ucapkan kepada Rumah Sakit $X$ yang mengijinkan tim peneliti untuk mengambil data. Terima kasih juga peneliti ucapkan untuk seluruh partisipan telah meluangkan waktu untuk berpartisipasi dalam penelitian ini.

\section{REFERENSI}


Aslund, C., Starrin, B., \& Nilsson, K. (2014). Psychosomatic symptoms and low psychological well-being in relation to employment status: The influence of social capital in a large cross-sectional study in Sweden. International Journal for Equity in Health. http://www.equityhealthj.com/content/13/1/22

Cheung, T., \& Yip, P. S. (2015). Depression, Anxiety and Symptoms of Stress among Hong Kong Nurses: A Cross-sectional Study. International Journal of Environmental Research and Public Health,12(9), 11072-11100. doi:10.3390/ijerph120911072

Eryuda, F. (2017). Hubungan shift kerja dan kelelahan kerja dengan stres kerja perawat di Instalasi Rawat Inap RSUD Dr. H. Abdul Moeloek Bandar Lampung (Unpublished undergraduate thesis). Universitas Lampung.

Etzion, D., Eden, D., \& Lapidot, Y. (1998). Relief from job stressors and burnout: Reserve service as a respite. Journal of Applied Psychology, 83, 577-585.

Fritz, C., Yankelevich, M., Zarubin, A., \& Barger, P. (2010). Happy, healthy, and productive: The role of detachment from work during nonwork time. Journal of Applied Psychology, 95(5), 977-983. doi:10.1037/a0019462

Greller, M., \& Parsons, C. K. (1988). Psychosomatic Complaints Scale of Stress [Database record]. Retrieved from PsycTESTS. doi: http://dx.doi.org/10.1037/t10630-000

Hasibuan, M. (2012). Manajemen Sumber Daya Manusia. Edisi Revisi. Bumi Aksara: Jakarta.

Hendarwati, M. (2015). Hubungan antara tingkat stres kerja perawat dengan kinerja perawat di Rumah Sakit Marga Husada Wonogiri (Unpublished undergraduate thesis). Sekolah Tinggi Ilmu Kesehatan Kusuma Husada.

Jundillah, Z. N. (2017). Analisis kejadian stres kerja pada perawat di Kabupaten Konawe Kepulauan (Unpublished undergraduate thesis). Universitas Halu Oleo.

Jusnimar. (2012). Gambaran tingkat stres kerja perawat intensive care unit (ICU) di Rumah Sakit Kanker Dharmais (Unpublished master's thesis). Universitas Indonesia.

Keyes, C. L. M., Shmotkin, D., Ryff, C. D. (1995). Optimizing well-being: The empirical encounter of two traditions. Journal of Personality and Social Psychology, Vol 82 (6), 1007-1022. HYPERLINK "http://psycnet.apa.org/doi/10.1037/00223514.82.6.1007"doi HYPERLINK "http://psycnet.apa.org/doi/10.1037/00223514.82.6.1007": 10.1037/0022-3514.82.6.1007

Kirk, A. (2015, January 17). Nurses at breaking point as number off work with stress soars. Retrieved May 17, 2017, from https://www.theguardian.com/society/2015/jan/17/nurses-nhs $\quad$-stress-leave-staffbreaking-point

Kristianti, E. (2016). Hubungan stres kerja dengan kinerja perawat dalam pendokumentasian asuhan keperawatan di ruang perawatan khusus RSUD Dr. Soediran Mangun Sumarso Wonogiri (Unpublished undergraduate thesis). Universitas Indonesia.

Martina, A. (2012). Gambaran tingkat stres kerja perawat di ruang rawat inap rumah sakit paru Dr. Moehammad Goenawan Partowidigdo Cisarua Bogor (RSPG) (Unpublished undergraduate thesis). Universitas Indonesia.

Parry, L. (2015, April 17). 12-hour nursing shifts are 'slave labour': Nurses' health 'put at risk' while patient safety suffers, union warns. Diambil May 26, 2017, from http://www.dailymail.co.uk/health/article-3043357/12-hour-nursing-shifts-slavelabourNurses-health-risk-patient-safety-suffers-union-warns.html

Petinandou, D., Daskagianni, E., Dimitrakaki, D., Kolaitis, D., \& Tountas, Y. (2013). The role of perceived well-being in the family, school and peer context in adolescents' subjective health complaints: evidence from a Greek cross-sectional study. Journal of the Japanese Society of Psychosomatic Medicine. doi: 10.1186/1751-0759-7-17 
Ratnaningrum, C. (2012). Tingkat stres perawat di ruang psikiatri intensif rumah sakit Dr. H. Marzoeki Mahdi Bogor (Unpublished undergraduate thesis). Universitas Indonesia.

Rivai, V. (2004). Manajemen sumber daya manusia untuk perusahaan: Dari teori ke praktik. Raja Grafindo Persada: Jakarta.

Robbins., Stephen, P., \& Timothy A. J. (2008). Perilaku organisasi. Salemba Empat: Jakarta.

Ryan, R. M., \& Deci, E. L. (2001). On happiness and human potentials: A review of research on hedonic and eudaimonic well-being. Department of Clinical and Social Science in Psychology. University of Rochester: NY.

Ryff, C. D. (1989). Happiness is everything or is it: Explorations on the meaning of psychological well-being. Journal of Personality and Social Psychology, 57 (6), 10681081. doi: 10.1037/1076-8998.10.4.393

Senecal, C., Vallerand, R. J., \& Guay, F. (2001). Emotional Exhaustion Scale [Database record]. Retrieved from PsycTESTS. doi: http://dx.doi.org/10.1037/t16260-000

Sonnentag, S., \& Bayer, U. (2005). Switching Off Mentally: Predictors and Consequences of Psychological Detachment From Work During Off-Job Time. Journal of Occupational Health Psychology, 10 (4), 393-414. doi:10.1037/1076-8998.10.4.393

Sonnetag, S. (2012). Psychological detachment from work during leisure time: The benefits of mentally disengaging from work. Journal of Psychological Science, 21 (2), 114-118. doi: $10.1177 / 0963721411434979$

Suryani, D. R., \& Waluyanti, F. T. (2013). Gambaran tingkat stres kerja perawat di unit perawatan intensif neonatus dan pediatrik RSUPN Dr. Cipto Mangunkusumo (Unpublished undergraduate thesis). Universitas Indonesia.

Wawancara dengan perawat [Wawancara personal]. (2017, May 26).

Wibowo, L. D. (2016). Gambaran tingkat stres kerja perawat di instalasi gawat darurat dan intensive care unit rumah sakit umum daerah Wates Kulon Progo (Unpublished undergraduate thesis). Sekolah Tinggi Ilmu Kesehatan Jenderal Achmad Yani Yogyakarta.

Wilk, S., \& Moynihan, L. M. (2005). Measure of Emotional Exhaustion [Database record]. Retrieved from PsycTESTS. doi: http://dx.doi.org/10.1037/t09304-000

Yana, D. (2015). Stres kerja pada perawat instalasi gawat darurat di RSUD Pasar Rebo Tahun 2014. Jurnal Administrasi Kebijakan Kesehatan,1(2), 107-115. Diambil May 17, 2017, dari http://journal.ui.ac.id/index.php/arsi/article/viewFile/5218/3503

Yu, A. (2016, April 15). Nurses Say Stress Interferes With Caring For Their Patients. Retrieved May 17, 2017, from http://www.npr.org/sections/healthshots/2016/04/15/474200707/nurses- say-stress-interferes-with-caring-for-their-patients 